\title{
A Review of Scientific Papers About Head and Neck Cancers
}

\author{
Severo de Paoli ${ }^{1,2,3,4}$, Adenilson de Souza da Fonseca ${ }^{1,6}$, Flávia de Paoli $^{1}$, Mauro Geller ${ }^{1}$, \\ Giuseppe Antonio Presta ${ }^{5}$, Sebastião David Santos-Filho ${ }^{6}$ and Mário Bernardo-Filho, \\ ${ }^{1}$ Centro Universitário Serra dos Órgãos; severodepaoli@gmail.com; Teresópolis - RJ - Brasil. ${ }^{2}$ Universidade \\ Estácio de Sá; Rio de Janeiro - RJ - Brasil. ${ }^{3}$ Universidade Federal Fluminense; Niterói - RJ - Brasil. ${ }^{4}$ Faculdade de \\ Odontologia de Nova Friburgo; Nova Friburgo - RJ - Brasil. ${ }^{5}$ Universidade Federal do Estado do Rio de Janeiro; \\ Rio de Janeiro - RJ - Brasil. ${ }^{6}$ Departamento de Biofísica e Biometria; Instituto de Biologia Roberto Alcantara \\ Gomes; Universidade do Estado do Rio de Janeiro; Rio de Janeiro - RJ - Brasil. ${ }^{7}$ Instituto Nacional do Câncer; \\ Coordenadoria de Pesquisa Básica; Rio de Janeiro - RJ - Brasil
}

\begin{abstract}
Head and neck cancer is one of the 10 most frequent cancers worldwide, with an estimated 500000 new cases diagnosed annually. Treatment of head and neck cancers require a multidisciplinary approach due their complexity and the functional and esthetic alterations that cancer can cause. The interest of the scientific community in a specific subject can be evaluated by analyzing of the number and the quality of published papers on the topic. The information obtained from PubMed (www.ncbi.nlm.nih.gov/sites/entrez) has been used as a tool in various publications to aid the evaluation of the scientific interest in specific research areas The aim of this work is to evaluate, using PubMed, the scientific interest in studies of head and neck cancer treatments such as radiotherapy, chemotherapy and surgery. The searches were performed on PubMed for publications from the period of 1949 to 2008 using the search terms "head and neck cancer" and "surgery" or "radiotherapy" or "chemotherapy". The number of publications per year was determined in each search. The percentage of publications was also calculated for each subject in each year. An interest factor in a subject (IFS) was also determined. The number of publications was higher for surgery than chemotherapy or radiotherapy. The calculated 1964 IFS for surgery was 14.79, 12.74 for radiotherapy, and 19.58 for chemotherapy. The 1995 IFS for surgery was 1.99, 2.09 for radiotherapy, and 2.08 for chemotherapy. The relation obtained for 1995 was maintained in the subsequent years. There are more publications related to surgical treatment for head and neck cancer when compared with radiotherapy and chemotherapy. Moreover, in the recent years there has an increased interest in treatments utilizing chemotherapy, or this associated to radiotherapy.
\end{abstract}

Key words: Scientific interest, PubMed, cancer, surgery, radiotherapy, chemotherapy

\section{INTRODUCTION}

Head and neck tumors have their origin, in the most cases and with exception of the skin tumors, in the aerodigestive tract mainly mucosa, mouth, pharynx and larynx (Ali, 2008; Jin et al.., 2008).
These include wide variety of malign neoplasms, each with distinct epidemiology, natural history, pathology, treatment and prognosis. Head and neck cancer is one of the 10 most frequent cancers worldwide, with an estimated 500000 new cases diagnosed annually (Chen et al., 2008).

\footnotetext{
${ }^{*}$ Author for correspondence
} 
A unifying feature of cancer is the uncontrolled proliferation and spread of cells, which alters the normal function of the surrounding or distant tissues, which may ultimately lead to organ failure and death (Schmit and Ahmad, 2007). The prototypic head and neck squamous cell carcinoma arises from the mucosal lining of the upper aerodigestive tract. It is the most frequent observed histological type identified in about $90 \%$ to $95 \%$ of cases. This type of cancer demonstrates squamous differentiation microscopically in older men with a long history of tobacco smoking and alcohol consumption, and is treated by multimodality therapy (Pai and Westra 2008).

The treatment of head and neck cancers require a multidisciplinary approach due to their complexity as well as the functional and esthetic alterations that cancer can cause (Haddad et al.., 2008). This multidisciplinary approach may include the involvement of professionals such as the head and neck surgeon, radiotherapist, clinical oncologist, speech therapist, plastic surgeon, dentist, nutritionist, physiotherapist and psychologist.

The selection of a conduct for the treatment of head and neck cancer must be adjusted to the necessity of each case. The patient and, when applicable, legal guardian should participate in the therapeutic decision after explanation of the risks and benefits of treatment alternatives. Treatment selection depends primarily on the location and stage of the tumor, general status and acceptance of the patient (Singh and Pfister, 2008; Mehanna et al., 2008; Specenier and Vermorken, 2007; Sanabria et al., 2007).

The surgery is indicated only in the cases of small easily removable lesions (Gulac et al., 2007). In most cases of hypopharynx tumors, the preferred treatment is surgical (Dubrulle et al., 2008). For organ preservation, concurrent chemoradiotherapy is usually preferred over surgery with adjuvant radiotherapy (Worden and Ha, 2008). Chemotherapy can be administered in patients with locoregionally advanced squamous cell carcinoma of the head and neck either concurrently with irradiation, as induction chemotherapy prior to local treatment, or as palliative therapy in patients with recurrent and/or metastatic disease (Specenier and Vermorken, 2008). Radiotherapy may be used to treat localized larynx tumors (Hoogsteen et al., 2006). This radiotherapy treatment depends basically on the location of the lesion, tumor extension, occurrence of metastatic lymph nodes, preference and needs of the patient, survival results and possibility of voice prevention. Thus radiotherapy is the treatment of choice for tumors of the glottis and small lesions of supraglottis (Nomiya et al., 2008). In the other situations where surgical treatment is selected, post-surgical radiotherapy may be administered (Lim et al., 2008; Rapidis, 2008).

The interest of the scientific community in a specific subject can be evaluated by the analysis of the number and the quality of papers published about the topic. Database and literature update systems play a relevant role in promoting the results of a research and how a topic is being used and accepted by the professionals in the area. PubMed

(http://www.ncbi.nlm.nih.gov/sites/entrez) is a service of the U.S. National Library of Medicine that includes over 18 million citations from MEDLINE and other life science journals for biomedical articles dated from the 1950s. PubMed includes, in general, the abstracts of the papers and links to various sites providing full text and other related resources. The information from PubMed has been used as a tool in various publications to aid the evaluation of the scientific interest in specific research areas, such as in acupuncture (Santos-Filho et al., 2003), moxibustion (SantosFilho et al., 2004), aging (Santos-Filho et al., 2006), liver disease (Gupta and Lewis, 2008), rosuvastatin (Soran and Durrington, 2008) and schizophrenia (Madaan et al., 2008).

The aim of this work is to evaluate, using PubMed, the scientific interest in the studies of head and neck cancer treatments specifically radiotherapy, chemotherapy and surgery.

\section{MATERIALS AND METHODS}

The searches were performed (August $30^{\text {th }}, 2008$ ) in the PubMed (http://www.ncbi.nlm.gov/sites/entrez) for publications dated from 1949 to 2008 using the search terms "head and neck cancer" and "surgery" or "chemotherapy" or "radiotherapy".

The number of publications (NP), in each year, was determined for "head and neck cancer and surgery" (HNC-S), "head and neck cancer and chemotherapy" (HNC-C) and "head and neck cancer and radiotherapy" (HNC-R). The total number of citations in each subject was also determined. 
The percentage of publications $(\% \mathrm{P})$ in each subject per year was calculated dividing the number of citations in each subject and in each year by the total number of citations in each subject for the studied period.

An interest factor in a subject (IFS) was also calculated by dividing the $\% \mathrm{P}$ in 2007 by the $\% \mathrm{P}$ in a specific year.

\section{RESULTS}

Table 1 shows the NP in head and neck cancer and some types of treatment in the studied period. The search term "surgery" yielded more publications than "radiotherapy" or "chemotherapy".

We observed a continuous and increased NP citing surgery, chemotherapy and radiotherapy in the treatment of head and neck cancer from 1949 to 2008 (Figs. 1, 2 and 3, respectively).

The IFS for surgery, radiotherapy and chemotherapy are shown in Table 2. The 1964 IFS for surgery was 14.79 , for radiotherapy was 12.74 and 19.58 for chemotherapy.

When calculated for 1995, the IFS for surgery was 1.99 , radiotherapy was 2.09 and chemotherapy was 2.08. These results were maintained in the subsequent years.

Table 1 - Number of publications in cancer and head and neck and types of treatment.

\begin{tabular}{lc}
\hline Treatment & Number of Publications \\
\hline Surgery & 23850 \\
Radiotherapy & 12131 \\
Chemotherapy & 9544 \\
\hline
\end{tabular}

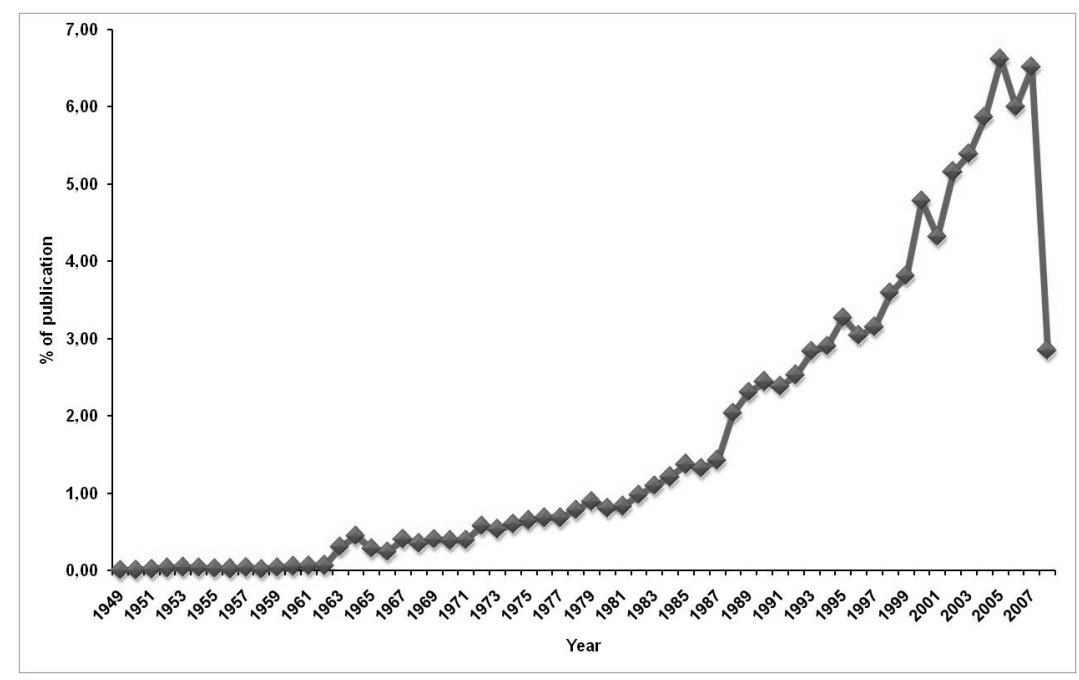

Figure 1 - Percentage of publication about surgery treatment of the head and neck cancer cited by year. 


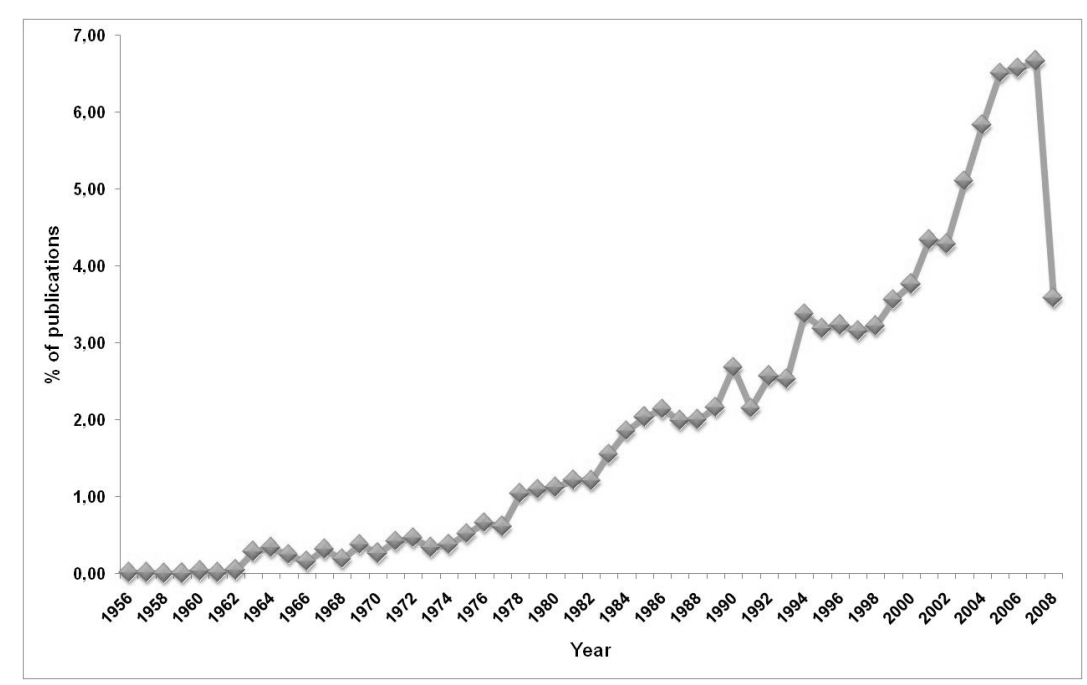

Figure 2 - Percentage of publication about chemotherapy of the head and neck cancer cited by year.

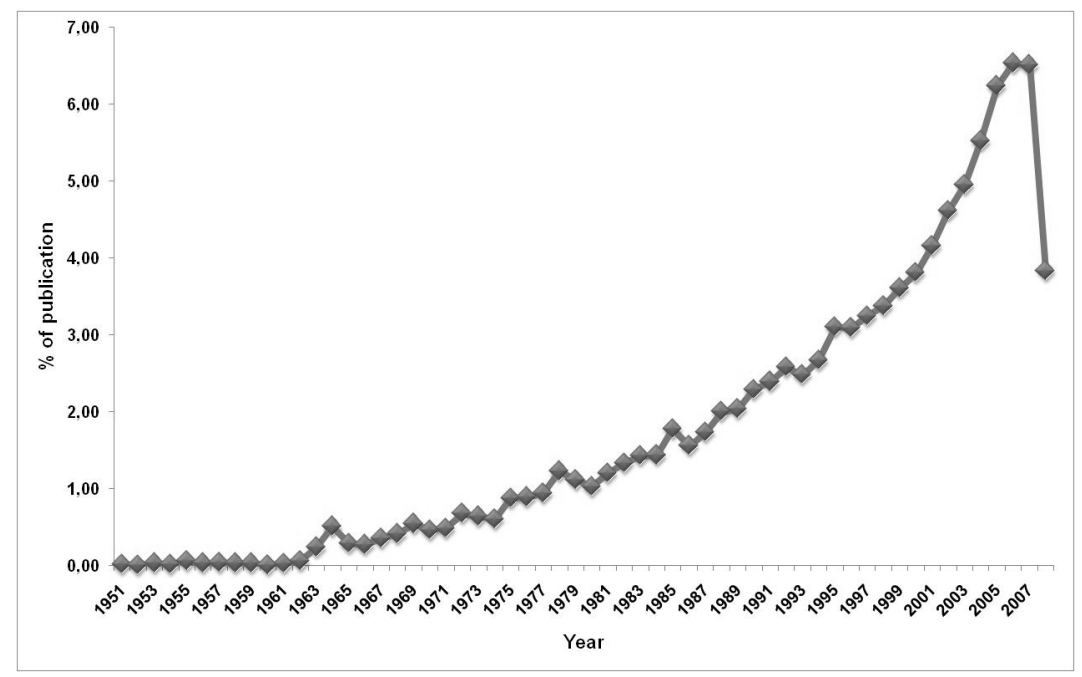

Figure 3 - Percentage of publication about radiotherapy of the head and neck cancer cited by year.

Table 2 - Interest factor subject (IFS) in surgery, radiotherapy and chemotherapy as head and neck cancer treatment.

\begin{tabular}{cccc}
\hline Period/Subject & Surgery & Radiotherapy & Chemotherapy \\
\hline $1964-2007$ & 14.79 & 12.74 & 19.58 \\
$1995-2007$ & 1.99 & 2.09 & 2.08 \\
$2005-2007$ & 0.98 & 1.04 & 1.02 \\
\hline
\end{tabular}

The IFS was calculated by dividing the \%P in 2007 by the $\% \mathrm{P}$ in 1964, 1995 and 2005 for HNC-S, HNC-R and HNC-C respectively. 


\section{DISCUSSION}

There are many different known types of cancer, each one with a specific etiology, treatment regime and prognosis (Missailidis, 2007). These conditions clearly indicate that various types of investigations are necessary in order to shed light on the different issues pertaining cancer and aid in early detection, as well as define the best possible form of treatment (Perkins, 2007).

The publication of a paper is as important as the results of the research itself, and is worthwhile: (i) to validate the obtained results and conclusions, (ii) to reach the targeted audience, (iii) to stimulate the discussion of a subject, (iv) to obtain recognition of the excellence of the work, (v) to announce the development of new methodologies and (vi) to have an international repercussion of the group that is developing the research. Database and literature update systems play an important role in promoting the results of research. The merit of scientific journals is evaluated by the impact factor. The impact factor is based on the analysis of the number of citations of published papers. The impact factor is determined by the Journal Citation Reports, a periodical publication that compiles the data of the Science Citation Index, Social Sciences Citation Index and Arts and Humanities Citation Index, all of which are published by the Institute for Scientific Information. The information found in the system database, PubMed, has been used as a tool by several investigators in various worthwhile studies that have been published (Santos-Filho et al., 2003, Santos-Filho et al., 2004, Santos-Filho et al., 2006; Gupta and Lewis, 2008; Soran and Durrington, 2008; Pettersson et al., 2008; Madaan et al., 2008).

The analysis of the results obtained in PubMed (Table 1, Figs. 1, 2, and Fig. 3) shows that when a subject is well accepted by the scientific community, the interest in the development of research is increased in the following years, i.e., surgery, radiotherapy and chemotherapy. Moreover, as show in Table 1 there are more publications related to surgical treatment for head and neck cancer when compared with radiotherapy and chemotherapy. Surgery as salvage treatment also continues to play an important role in organ preservation strategies in advanced head and neck cancer (Dequanter and Lothaire, 2008).
In our search of PubMed the first publications found in HNC-C was dated 1956; the first publication related to HNC-R was dated 1951 and 1949 for HNC-S. The analysis of Table 2 reveals that the \%P in all subjects has suffered a strong variation. If one considers the period between 1964 and 1995, the comparison of the interest factor is higher for chemotherapy than surgery or radiotherapy. However, the same comparison between 1995 and 2005 shows that the interest factor is almost the same. The application of chemotherapy in head and neck tumors is still under investigation. In the recent years there has been an increased interest in protocols for organs preservation, utilizing chemotherapy associated to radiotherapy, as well as these associations as therapeutic neo-adjuvant in advanced local tumors.

\section{CONCLUSION}

There are more publications related to surgical treatment for head and neck cancer when compared with radiotherapy and chemotherapy. Moreover, in the recent years there has been an increased interest in treatments utilizing chemotherapy, or this associated to radiotherapy.

\section{RESUMO}

O câncer de cabeça e pescoço é um dos 10 mais freqüentes cânceres no mundo, com um número de 50000 novos casos diagnosticados anualmente. O tratamento dos cânceres de cabeça e pescoço requer uma abordagem multidisciplinar devido a sua complexidade e a alterações funcionais e estéticas que o câncer pode causar. O interesse da comunidade científica em um objeto pode ser avaliado pela análise do número e da qualidade dos artigos publicados. A informação obtida do PubMed (www.ncbi.nlm.nih.gov/sites/entrez) tem sido usada como uma ferramenta em várias publicações para ajudar a avaliação do interesse científico em áreas de pesquisa específicas. O objetivo desse trabalho é avaliar, usando o PubMed, o interesse científico em estudar os tratamentos do câncer de cabeça e pescoço, tais como a radioterapia, a quimioterapia e a cirurgia. As pesquisas foram realizadas no PubMed para publicações de 1949 a 2008 usando os termos de pesquisa "head and neck cancer" e "surgery" ou 
"radiotherapy" ou "chemotherapy". O número de publicações (NP) por ano foi determinado para cada pesquisa. A percentagem de publicações (\%) também foi calculada para cada objeto em cada ano. Um fator de interesse em um objeto (IFS) também foi determinado. O NP foi maior para cirurgia do que para quimioterapia ou radioterapia. O IFS calculado em 1964 para cirurgia foi 14,79; 12,74 para radioterapia; e 19,58 para quimioterapia. Em 1995 o IFS foi 1,99 para cirurgia, 2,09 para radioterapia e 2,08 para quimioterapia. A relação obtida para 1995 foi mantida nos anos subseqüentes. Existem mais publicações relacionadas ao tratamento cirúrgico para o câncer de cabeça e pescoço quando comparadas com radioterapia ou quimioterapia. Além disso, nos últimos anos tem existido um aumento no interesse em tratamentos utilizando a quimioterapia, ou ela associada à radioterapia.

\section{REFERENCES}

Ali, Mel-S. (2008), Laryngopharyngeal reflux: diagnosis and treatment of a controversial disease. Curr Opin Allergy Clin Immunol., 8, 28-33.

Chen, Y. J.; Chang, J. T.; Liao, C. T.; Wang, H. M.; Yen, T. C.; Chiu, C. C.; Lu, Y. C.; Li, H. F.; Cheng, A. J. (2008), Head and neck cancer in the betel quid chewing area: recent advances in molecular carcinogenesis. Cancer Sci., 99, 1507-1514.

Dequanter, D.; Lothaire, P. (2008), Therole of salvage surgery in organ preservation strategies in advanced head and neck cancer. B-Ent., 4, 77-80.

Dubrulle, F.; Souillard, R.; Chevalier, D.; Puech, P. (2008), Imaging of tumors of the larynx and hypopharynx. J Radiol., 89, 998-1012.

Gulec, S. A.; Hoenie, E.; Hostetter, R.; Schwartzentruber, D. (2007), PET probe-guided surgery: applications and clinical protocol. World $J$ Surg Oncol., 5, 65.

Gupta, N. K.; Lewis, J. H. (2008), The use of potentially hepatotoxic drugs in patients with liver disease. Aliment Pharmacol Ther., in press.

Haddad, R.; Annino, D.; Tishler, R. B. (2008), Multidisciplinary approach to cancer treatment: focus on head and neck cancer. Dent Clin North Am., 52, 117.

Hoogsteen, I. J.; Pop, L. A.; Marres, H. A.; Merkx, M. A.; van den Hoogen, F. J.; van der Kogel, A. J.; Kaanders, J. H. (2006), Oxygen-modifying treatment with ARCON reduces the prognostic significance of hemoglobin in squamous cell carcinoma of the head and neck. Int J Radiat Oncol Biol Phys., 64, 83-89.
Jin, C.; Jin, Y.; Wennerberg, J.; Rosenquist, B.; Mertens F. (2008), Increased sensitivity to bleomycin in upper aerodigestive tract mucosa of head and neck squamous cell carcinoma patients. Mutat Res., 652, 30-37.

Lim, Y. C.; Hong, H. J.; Baek, S. J.; Park, J. H.; Kim, G. E.; Lee, C. G.; Lew, D. H.; Lee, W. J.; Choi, E. C. (2008), Combined surgery and postoperative radiotherapy for oropharyngeal squamous cell carcinoma in Korea: analysis of 110 cases. Int J Oral Maxillofac Surg., in press.

Madaan, V.; Dvir, Y.; Wilson, D. R. (2008), Child and adolescent schizophrenia: pharmacological approaches. Expert Opin Pharmacother., 9, 20532068.

Mehanna, H. M.; De Boer, M. F.; Morton, R. P. (2008), The association of psycho-social factors and survival in head and neck cancer. Clin Otolaryngol., 33, 8389.

Missailidis, S. (2007), Genetics and cancer. In-The Cancer Clock, Missailidis S (editor). John Wiley and Sons Ltd, West Sussex, England.

Nomiya, T.; Nemoto, K.; Wada, H.; Takai, Y.; Yamada, S. (2008), Long-term results of radiotherapy for T1a and T1bNOM0 glottic carcinoma. Laryngoscope., 118, 1417-1421.

Pai, S. I.; Westra, W. H. (2008), Molecular pathology of head and neck cancer: implications for diagnosis, prognosis, and treatment. Annu Rev Pathol., in press.

Perkins, A. (2007), Tumour imaging and Terapy. InThe Cancer Clock, Missailidis S (editor). John Wiley and Sons Ltd, West Sussex, England.

PubMed http://www.ncbi.nlm.nih.gov/entrez/query.fcgi accessed in August, 30th, 2008.

Rapidis, A. D. (2008), Sarcomas of the head and neck in adult patients: current concepts and future perspectives. Expert Rev Anticancer Ther., 8, 12711297.

Sanabria, A.; Carvalho, A. L.; Vartanian, J. G.; Magrin, J.; Ikeda, M. K.; Kowalski, L. P. (2007), Factors that influence treatment decision in older patients with resectable head and neck cancer. Laryngoscope., 117, 835-840.

Santos-Filho, S. D.; Bastos, S. R. C.; Pereira, F. A. O.; Senna Fernandes, V.; França, D.; Guilhon, S.; Bernardo-Filho, M. (2003), An evaluation of scientific papers about acupuncture. J Aust Tradit Med Soc., 9, 185-187.

Santos-Filho, S. D.; Bastos, S. R. C.; Pereira, F. A. O.; Senna Fernandes, V.; França, D.; Guilhon, S.; Bernardo-Filho M. (2004), Traditional medicine: an evaluation of the interest of the publication of scientific papers about moxibustion. J Med Sci., 4, 56-62. 
Santos-Filho, S. D.; Manoel, C. V.; Silva, G. A.; Duarte, V. S.; Rodrigues, G. N.; Andrade, M. L.; Bernardo-Filho, M. (2006), O interesse científico no estudo do envelhecimento e prevenção em ciências biomédicas. Rev Bras Ciên Envelh Hum., 3, 70-78.

Schmit, T. L.; Ahmad, N. (2007), Regulation of mitosis via mitotic kinases: new opportunities for cancer management. Mol Cancer Ther., 6, 1920-1931.

Singh, B.; Pfister, D. G. (2008), Individualized treatment selection in patients with head and neck cancer: do molecular markers meet the challenge? $J$ Clin Oncol., 26, 3114-3116.

Soran, H.; Durrington, P. (2008), Rosuvastatin: efficacy, safety and clinical effectiveness. Expert Opin Pharmacother., 9, 2145-2160.
Specenier, P. M.; Vermorken, J. B. (2007), Neoadjuvant chemotherapy in head and neck cancer: should it be revisited? Cancer Lett., 256, 166-177.

Specenier, P. M.; Vermorken, J. B. (2008), Current concepts for the management of head and neck cancer: Chemotherapy. Oral Oncol., in press.

Worden, F. P.; Ha H. (2008), Controversies in the management of oropharynx cancer. J Natl Compr Canc Netw., 6, 707-714.
Received: August 20, 2008; Revised: September 10, 2008; Accepted: September 13, 2008. 